\title{
Efficacy of Biological and Chemical Treatments for the Management of Damping Off (Pythium Spp.) of Bitter Gourd in the Nursery
}

\author{
Manisha Mahat ${ }^{1}$ and Subash Gautam ${ }^{2 *}$
}

\author{
${ }^{1}$ Nepal Polytechnique Institute, Purbanchal University, Bharatpur, Nepal \\ Email: manishamahat93@gmail.com \\ ${ }^{2}$ Department of Plant Pathology, Agriculture and Forestry University, Rampur, Nepal \\ Email: goodinsense@gmail.com
}

\begin{abstract}
A field experiment on "Efficacy of Biological and Chemical Treatments for the management of Damping Off (Pythium Spp.) of Bitter Gourd in the nursery" was conducted during March $1^{\text {st }} 2017$ to April 18 th $^{\text {2017. The }}$ experiment was laid out in Randomized Complete Block Design (RCBD) with seven treatments and three replications. The treatments included biocontrol agent as Trichodermaharzianum( $\left.1 \times 10^{6} \mathrm{CFU} / \mathrm{ml}\right)$, Vitavex $(0.1 \%)$, Bavistin (2 $\mathrm{g} / \mathrm{kg}$ of seed) and Mancozeb $75 \%$ WP (2 $\mathrm{g} / \mathrm{kg}$ of seed) as chemical treatments and integration of bio control agent and chemicals were used. The germination percentage, pre and post emergence damping off of bitter gourd seedlings were recorded. The significant; increment in germination percentage $(120 \%)$,reduction in pre and post disease incidence (92\% and $89 \%$ ) was found in seed treatment of Vitavex(0.1\%) + soil treatment with Trichoderma $\left(1 \times 10^{6} \mathrm{CFU} / \mathrm{ml}\right)$ and it was followed by seed treatment with Bavistin (2 $\mathrm{g} / \mathrm{kg}$ of seed). It was may be due to the inhibitory effect of fungicide Vitavex on development of seed borne pathogen reducing seedling mortality at an early stage followed by vigorous root and shoot development as affected by the antagonistic and hormonal effect of the Trichodermaharzianum.
\end{abstract}

Keyword-Pythium spp.; damping off; Trichoderma; biocontrol agent.

\section{INTRODUCTION}

Bitter gourd (Momordicacharantia) is a tropical and subtropical vine of the family Cucurbitaceaeis known variously as bitter gourd, balsam pear, bitter melon, bitter cucumber and African cucumber (Heiser 1979).It is widely grown in Asia, Africa, and South America (Raj et. al., 1993, Singh 1984). Area cultivated of bitter gourd in Chitwan is 435 ha with the production of $6090 \mathrm{mt}$ and productivity of $14.0 \mathrm{mt} / \mathrm{ha}$. Whereas total area cultivated of bitter gourd in
Nepal is 10082.2 ha with the production of $132350.1 \mathrm{mt}$ and productivity of $13.1 \mathrm{mt} / \mathrm{ha}$ (MOAD,2016).

Damping off is the most common disease of the seedling vegetables. Buchenauer, 1998; Vogt and Buchenauer, 1997 reported that Damping off is the important soil-borne disease attacking plants. The two fungi that are most often associated with damping-off are Rhizoctoniasolani and Pythium species. The most aggressive species of Pythium that causes important plant diseases is P.aphanidermatum. It is a soil as well as seed born pathogen. It is the most important and responsible for pre and post emergence damping off of seedlings. Damping-off disease by Pythium species causes more than 60 percent mortality of seedlings both in nursery and main field (Manoranjithamet. al., 2000). For the management of the damping off disease chemical fungicides is considered to be easiest and the fastest method. Apart from the disease control aspects of pesticide we cannot undermine its detrimental effects in environment. The over application of chemical fertilizer and pesticide reduce farm profits, create a risk of soil degradation and cause environmental pollution (Trisdale, Nelson and Beaton, 1985).Biological control offers environment friendly approach for the management of plant disease and can be incorporated into cultural and physical controls methods and also very limited chemical usage for an effective integrated pest management system (Monte 2010). This research was mainly focused in effective yet environment friendly approach of damping off management to produce healthy seedling of the bitter gourd plant so that farmers can gain more income from the bitter gourd production. The major objective of this study was to find out the efficacy of biological and chemical treatments for the management of damping-off (Pythium spp.) of bitter gourd in the nursery. 


\section{MATERIALS AND METHODS}

\section{Selection of treatments}

The commonly grown variety White Long was brought from Anamolbiu Private Limited Company, Bharatpur-12 Chitwan for the experiment. A total of 7 treatments including control were selected for the experiment .The treatments applied in the field were also used in the laboratory for seed treatment. The details of the treatments are as follows:

Table.1: Details of the treatments used for experiment

\begin{tabular}{|c|c|c|}
\hline SN & Treatments & Symbol \\
\hline 1 & Seed treatment with $0.1 \%$ Vitavex + Soil treatment with Trichodermaharzianum@ $10^{6} \mathrm{cfu} \mathrm{ml}^{-1}$ & T1 \\
\hline 2 & Seed treatment with Vitavex @ 2 $\mathrm{g} \mathrm{kg}^{-1}$ & $\mathrm{~T} 2$ \\
\hline 3 & Seed treatment with Bavistin (Carbrendazim 50\%WP) @ 2 $\mathrm{g} \mathrm{kg}^{-1}$ & $\mathrm{~T} 3$ \\
\hline 4 & Seed treatment with Mancozeb 75\%WP @ 2. kg & $\mathrm{T} 4$ \\
\hline 5 & Soil treatment with Trichodermaharzianum@ 10 ${ }^{6} \mathrm{CFU} / \mathrm{ml}$ & T5 \\
\hline 6 & Seed treatment with Trichodermaharzianum @ 106 $\mathrm{cuu} / \mathrm{ml}$ & T6 \\
\hline 7 & Control & $\mathrm{T} 7$ \\
\hline
\end{tabular}

\section{Collection of fungicide and bio-control agent}

Systemic fungicides like Vitavex, Bavistin and contact fungicide like Mancozeb were collected from the local market of Narayanghat and UnnatBijBriddi Farmers Group Patihani-5 of Chitwan district and the pure culture of biocontrol agent (Trichodermaharzianum) was acquired from AFU Rampur Chitwan.

\section{Preparation of Trichoderma solution}

A fully grown Trichoderma PDA plate was scraped with sterilized cotton to collect spores. Those spores were filtered through muslin cloth and then collected on sterilized beaker and diluted using sterilized distilled water. The concentration of the spores was checked using haemocytometer after dilution to obtain the required concentration of $10^{6}$ conidia $\mathrm{ml}^{-1}$. The concentration of $10^{6}$ conidia $\mathrm{ml}^{-1}$ was used for soil and seed treatment.

\section{Preparation of the chemical fungicides}

Chemical fungicides like Bavistin, Mancozeb and Vitavex at the rate of $2 \mathrm{~g} \mathrm{~kg}^{-1}$ were taken for seed treatment and seed were treated accordingly.

\section{Experimental design}

The experiment was conducted in one factor RCBD with 3 replications. Seven different treatments were used as mentioned on Table no 1 .There were 21 plots with an individual plot size of $50 * 50 \mathrm{~cm}$. Inter block and inter plot spacing were $50 \mathrm{~cm}$ and $20 \mathrm{~cm}$ respectively. Treatments were randomly allocated in experimental units.

\section{Seed treatment}

Seed treatment was done in the plant pathology lab of NPI. Required amount of Trichodermaharzianum spore suspension@10 $\mathrm{CFU} / \mathrm{ml}$ and seeds from related treatments were kept in a $250 \mathrm{ml}$ conical flask and were shaken mechanically for 10 minutes for proper coating of bio fungicide. Same procedure was applied for seed treatment with different fungicides.

Application of treatments in the field

Trichodermaharzianum soil application@106 CFU/ml was done by soil drenching before the seeds were sown. Spray formulation were sprayed using different hand sprayer for each treatments.

\section{Observation in field}

Observation was done on regular basis to record the data of germinated seedlings and to record the data of other parameters (seedling height, root weight, shoot weight), ten sample plants were randomly selected and tagged for further observation.

$$
\begin{aligned}
& \text { Germination } \%=\frac{\text { No of seeds germinated }}{\text { Total no of seeds sown }} \times 100 \\
& \begin{aligned}
\text { Disease incidence } \% \\
=\frac{\text { No of infected seedlings }}{\text { Total no of seedlings in a plot }} \\
\times 100
\end{aligned}
\end{aligned}
$$

\section{Data collection and analysis}

The recorded data were tabulated in Excel data sheet and were analyzed by using Gen stat software program. The data entry was done to develop ANOVA table and different treatments were compared through Duncan's multiple range test. All the figures and graphs were prepared by using Microsoft excel 2013.

\section{RESULTS AND DISCUSSION}

Efficacy of chemical fungicide and biological agent seed and soil treatments on germination of bitter gourd seed In case of germination percentage of Bitter gourd seedling, analysis of variance (ANOVA) revealed significant difference between the treatments. Mean germination 
percentage of bitter gourd after the application of Trichodermaharzianum $\left(10^{6} \mathrm{CFU} / \mathrm{ml}\right)$ in the soil along with vitavex seed treatment was $95 \%$, whereas seed treatment with Bavistin was $84 \%$ and control had significantly lowest germination percentage $(43 \%)$ than other treatments. Combined efficacy of vitavex and Trichoderma resulted in higher germination percentage (Table 1). The Trichodermaharzianum was found effective in reducing disease incidence and increasing crop germination (Shanmugam, Varma and Surendran 1999). Also Trichoderma was found most effective in reducing seedling mortality and root infection (increase in plant no.) in cucumber and bottle gourd (Sultan and Ghafar 2013) and this may be due to Trichoderma species being capable of producing extracellular lytic enzymes that are responsible for their antagonistic activity (Eladet. al.,, 1982). The chemical seed treatment with Carbendazim (Bavistin) also helped for higher germination percentage $(85 \%)$. Other scientist also reported that Benlate, Carbendazim and Topsin-M completely checked seedling mortality in bottle gourd (Shazad 1994 and Sultan and Ghafar 2013). However, highest increase in germination as compare to control was recorded on Soil treatment with Trichoderma+Vitavex seed treatment followed by Bavistin seed treatment. Present research clearly indicated that combined use of seed treatment with $0.1 \%$ Vitavex and soil treatment with Trichodermaharzianum is the best option for the management of damping-off disease of bitter gourd seedlings in the nursery among other treatments. It may be due to the inhibitory effect of vitavex and the antagonistic activity of Trichodermaharzianumfor the reduction of seedling mortality and increment of germination for the production of healthy seedlings in the nursery.

Table.1: Effect of seed treatment by chemical fungicides and biological agent on germination of bitter gourd seed

\begin{tabular}{|c|c|c|}
\hline Treatments & Germination \% & $\begin{array}{l}\text { Increase in Germination } \\
\%\end{array}$ \\
\hline Seed treatment with $0.1 \%$ Vitavex + Soil treatment with & $95.33^{f}$ & 120.01 \\
\hline \multicolumn{3}{|l|}{ Trichodermaharzianum @ 106 CFU/ml } \\
\hline Seed treatment with Vitavex @ 2 $\mathrm{g} \mathrm{kg}^{-1}$ & $78.00^{\mathrm{d}}$ & 80.01 \\
\hline Seed treatment with Bavistin (Carbrendazim 50\%WP) @ 2g kg-1 & $84.67^{\mathrm{e}}$ & 95.41 \\
\hline Seed treatment with Mancozeb 75\%WP @ 2. kg & $72.00^{\mathrm{dbc}}$ & 66.17 \\
\hline Soil treatment with Trichodermaharzianum @ 106 CFU/ml & $75.00^{\mathrm{cd}}$ & 73.09 \\
\hline Seed treatment with Trichodermaharzianum @ 106 CFU/ml & $69.00^{\mathrm{b}}$ & 59.24 \\
\hline Control & $43.33^{\mathrm{a}}$ & \\
\hline Grand Mean & 73.9 & \\
\hline $\operatorname{SEm}( \pm)$ & 2.12 & \\
\hline P-value & $<.001$ & \\
\hline $\operatorname{LSD}(=0.05)$ & 3.78 & \\
\hline $\mathrm{CV}(\%)$ & 2.9 & \\
\hline
\end{tabular}

Mean in a column with same letters are not significantly different $(\mathrm{p}=0.05)$ according to DMRT, $\mathrm{CV}=\mathrm{Coefficient}$ of variation, $\mathrm{LSD}=$ Least significance Difference, $*=$ significantly different at $(\mathrm{P}<0.05), * *=$ highly significantly different at $(\mathrm{P}<0.01), * * *=$ very highly significantly different at $(\mathrm{P}<0.001)$.

Efficacy of chemical fungicides and biological agent on seed and soil treatments on damping off disease

In case of pre emergence damping off disease incidence caused by Pythium spp., Analysis of Variance (ANOVA) revealed significant difference between the treatments. The lowest pre emergence damping off disease percentage was recorded in seed treatment with $0.1 \%$ Vitavex + soil treatment with $10^{6} / \mathrm{ml}$ Trichodermaharzianum (3.33\%) which was followed by seed treatment with Bavistin (12.67\%), seed treatment with Vitavex @ $2 \mathrm{~g} \mathrm{~kg}^{-1}(18.67 \%)$ respectively. Also, in case of post emergence damping off disease incidence caused by Pythium spp., Analysis of Variance (ANOVA) revealed significant difference between the treatments. The lowest post emergence damping off disease percentage was recorded in seed treatment with $0.1 \%$ Vitavex + soil treatment with $10^{6} / \mathrm{ml}$ Trichodermaharzianum $(1.33 \%)$ which was statistically at par with other treatments viz. Seed treatment with Mancozeb 75\%WP @ $2 \mathrm{~g} \mathrm{~kg}^{-1}$ $(1.33 \%)$,Seed treatment with Bavistin (Carbrendazim $50 \% \mathrm{WP}) @ 2 \mathrm{~g} \mathrm{~kg}^{-1}(2.66 \%)$, Seed treatment with $10^{6} / \mathrm{ml}$ Trichodermaharzianum (2.67\%), Soil treatment with $10^{6} / \mathrm{ml}$ Trichodermaharzianum (3.33\%), Seed treatment with 
Vitavex@2 $\mathrm{g} \mathrm{kg}^{-1}$ (3.33\%)except control which had the highest $(12.33 \%)$ post emergence disease incidence (Table 2).

In the present study, the pre emergence damping off disease incidence reduction was highest in seed treatment with $0.1 \%$ Vitavex + Soil treatment with $10^{6} / \mathrm{ml}$ Trichodermaharzianum $(92.49 \%)$ followed by seed treatment with Bavistin (Carbrendazim 50\%WP) (71.42\%). Similarly, in case of post emergence damping off disease incidence, highest reduction in incidence was found in seed treatment with $0.1 \%$ Vitavex + Soil treatment with $10^{6} / \mathrm{ml}$ Trichoderma $(89.21 \%)$ followed by Seed treatment with Mancozeb 75\%WP (89.21\%) (Figure 1).These results indicated that pre and post emergence damping off of bitter gourd seedling was significantly reduced by using different treatments as compare to control.

The Trichodermaharzianum was found effective in reducing disease incidence and increasing crop germination
(Shanmugam, Varma and Surendran 1999). Synthetic fungicides bring about the inhibition of pathogens either by destroying their cell membrane or its permeability or by inhibiting metabolic processes of the pathogens and hence are extremely effective (Osman, Alrehiayam, Saudi and Bio 2003). Trichoderma species are capable of producing extracellular lytic enzymes that are responsible for their antagonistic activity (Eladet. al.,, 1982). As the findings made by different researchers above in discussion viz. antagonistic behavior of Trichodermaspp.due to extracellular lytic enzymes production and inhibitory effect of synthetic fungicide like vitavex by may be reason behind the significant control in pre and post emergence disease incidence with the use of different chemical and biological treatments. Also the combined antagonistic effect of Trichoderma and inhibitory effect of vitavex was found to be best in controlling pre emergence (92\%) and post emergence (89\%) damping off caused by Fusariumand Pythium spp.

Table.2: Effect of seed treatment with chemicalfungicides and biological agent on disease incidence of pre and post damping off disease of bitter gourd in seedling stage

\begin{tabular}{|c|c|c|c|c|c|}
\hline Treatments & $\%$ Pre-emergence & \% Disease & $\% \quad$ Post & $\%$ & Disease \\
\hline & DI & Control & emergence DI & control & \\
\hline $\begin{array}{l}\text { Seed treatment with } 0.1 \% \text { Vitavex }+ \text { Soil treatment } \\
\text { with Trichodermaharzianum @ } 10^{6} \mathrm{CFU} / \mathrm{ml}\end{array}$ & $3.33^{\mathrm{a}}$ & 92.49 & $1.33^{\mathrm{a}}$ & 89.21 & \\
\hline Seed treatment with Vitavex @ $2 \mathrm{~g} \mathrm{~kg}^{-1}$ & $18.67^{\mathrm{c}}$ & 57.88 & $3.33^{\mathrm{a}}$ & 72.99 & \\
\hline $\begin{array}{l}\text { Seed treatment with Bavistin (Carbrendazim 50\%WP) } \\
\text { @ } 2 \mathrm{~g} \mathrm{~kg}^{-1}\end{array}$ & $12.67^{\mathrm{b}}$ & 71.42 & $2.66^{\mathrm{a}}$ & 78.43 & \\
\hline Seed treatment with Mancozeb 75\%WP @ $2 \mathrm{~g} \mathrm{~kg}^{-1}$ & $26.67^{\mathrm{de}}$ & 39.84 & $1.33^{\mathrm{a}}$ & 89.21 & \\
\hline $\begin{array}{l}\text { Soil treatment with Trichodermaharzianum @ } \\
10^{6} \mathrm{CFU} / \mathrm{ml}\end{array}$ & $21.67^{\mathrm{cd}}$ & 51.12 & $3.33^{\mathrm{a}}$ & 72.99 & \\
\hline $\begin{array}{l}\text { Seed treatment with Trichodermaharzianum @ } \\
10^{6} \mathrm{CFU} / \mathrm{ml}\end{array}$ & $28.33^{\mathrm{e}}$ & 36.09 & $2.67^{\mathrm{a}}$ & 78.35 & \\
\hline Control & $44.33^{\mathrm{f}}$ & & $12.33^{\mathrm{b}}$ & & \\
\hline Grand Mean & 22.24 & & 3.86 & & \\
\hline $\operatorname{SEm}( \pm)$ & 2.7 & & 1.32 & & \\
\hline P-value & $<.001$ & & $<.001$ & & \\
\hline $\operatorname{LSD}(=0.05)$ & 5.89 & & 3.35 & & \\
\hline $\mathrm{CV}(\%)$ & 14.9 & & 42.2 & & \\
\hline
\end{tabular}

Mean in a column with same letters are not significantly different ( $\mathrm{p}=0.05)$ according to DMRT, $\mathrm{CV}=\mathrm{Coefficient}$ of variation, LSD=Least significance Difference, ${ }^{*}=$ significantly different at $(\mathrm{P}<0.05), * *=$ highly significantly different at $(\mathrm{P}<0.01), * * *=$ very highly significantly different at $(\mathrm{P}<0.001)$. 


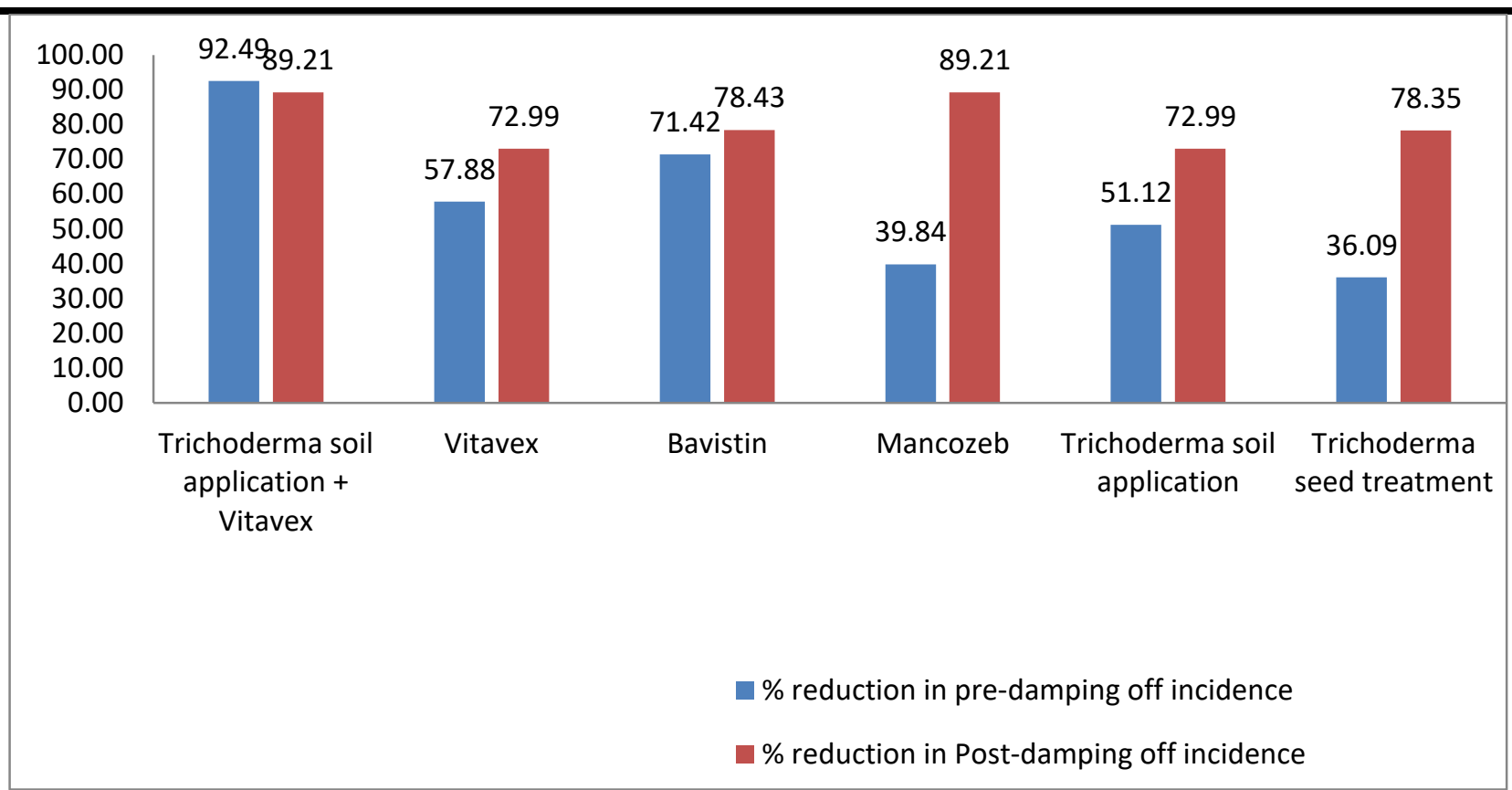

Fig.1: Percentage reduction in pre and post emergence damping off disease incidence of bitter gourd due to different seed treatments

\section{CONCLUSION}

The use of Trichodermaharzianumin soil along with Vitavex in seed showed the best result among all other treatment. However use of Trichodermaharzianum in soil only also showed significant reduction in post and pre emergence disease incidence resulting higher germination percentage, plant height and healthy root system. This may be due to the inhibitory effect of chemical fungicide Vitavex for the growth of pathogen and hormonal effect produce by Trichodermaharzianum to stimulate vigorous root and shoot growth of the bitter gourd seedlings. This study was mainly focused on the only one dosage of chemical fungicide and single isolate of Trichoderma on the control of Pythium spp. Furthermore, study can be carried out to find out the best dosage of chemical fungicides, best conidial concentration of Trichoderma and best isolate of Trichoderma. Also the best combination and benefit cost ratio could be identified between bio control agent and chemical fungicide.

\section{ACKNOWLEDGEMENT}

The authors are thankful to Nepal Polytechnic Institute (NPI) Bhojad-11, Bharatpur, Chitwan for providing research site and lab facility. Also author would like to show gratitude towards Agriculture and Forestery University Nepal, Prof. Sundar Man Shrestha and Senior Scientist, Nepal Agriculture and Research Council, SubashSubedi for the support and guidance during the research.

\section{REFERENCES}

[1] Buchenauer H (1998) Biological control of soil-borne disease by rhizobacteria. J Plant Dis Prot 105(4):329348

[2] Elad Y, Kalfon A and Chet (1982) Control of Rhizoctoniasplani in cotton by seed-coating with Trichoderma spp. spores. Plant Soil 66: 279-281.

[3] Heiser CB (1979)The gourd book. University of Oklahoma Press, Norman, OK.

[4] Manoranjitham SK, Prakasam V, Rajappan K and Amutha G (2000) Control of chilli damping-off using bio-agents.Journal of Mycology and Plant Pathology, 30: $225-228$

[5] MoAD (2016) Statistical Information on Nepalese Agriculture, Ministry of Agricultural Development, 2015/16

[6] MonteE(2010) Understanding Trichoderma: between biotechnology and microbial ecology. International Microbiology, 4(1), 1-4

[7] Osman KA\&Abdulrahman HT (2003) Risk assessment of pesticide to human and the environment.Saudi $J$. Biol. Sci, 10, 81-106.

[8] Raj M, Prasanna NKP and Peter KV (1993) Bitter gourd Momordica ssp. In: Kalloo G, Berg BO (eds) Genetic improvement of vegetable crops. Oxford: Pergamon Press, pp 239-246

[9] Shahzad S (1994) Studies on soil borne root infecting fungi with special reference to the control of root rot 
and root knot disease complex Ph. D Thesis. Dept. Bot.,

Univ.Karachi, Pakistan.pp. 299.

[10] Shanmugam V, Varma AS and Surendran M (1999)

Management of rhizome rot of ginger by antagonistic microorganisms. Madras, Agric. J. 86: 339341.

[11] Singh RS(1984) Diseases of vegetable crops.Oxpord \& IBH Publishing Co. New Delhi. pp: 512

[12] Sultana NASREEN and Ghaffar A (2013) Effect of fungicides, microbial antagonists and oil cakes in the control of Fusariumoxysporum, the cause of seed rot and root infection of bottle gourd and cucumber. Pak. J. Bot, 45(6), 2149-2156.

[13] Tisdale SL and Nelson WL(1958)Soil fertility and fertilizers.Macmillan Company.; New York.

[14] VogtW and Buchenauer H(1997) Enhancement of biological control by combination of antagonistic fluorescent Pseudomonas strains and resistance inducers against damping off and powdery mildew in cucumber.Zeitschriftü̈rPflanzenkrankheiten und Pflanzenschutz/Journal of Plant Diseases and Protection, 272-280. 